Studies were financed by the Ministry of Health, and the present study was also supported by a grant to one of us (R. J. J.) from Lilly Laboratories.

\section{REFERENCES}

Bowen, A. J., and Reeves, R. L. (1967). Archives of Internal Medicine, 119, 261.

Doe, R. P., Flink, E. B., and Goodsell, M. G. (1956). Fournal of Clinical Endocrinology, 16, 196.

Freinkel, N., Mager, M., and Vinnick, L. (1968). Fournal of Laboratory and Clinical Medicine, 71, 171.

Hayner, N. S., Kjelsberg, M. D., Epstein, F. H., and Francis, T., jun. (1965). Diabetes, 14, 413.
Keen, H., Jarrett, R. J., Chlouverakis, C., and Boyns, D. R. (1968). Postgraduate Medical fournal, 44, 960.

McDonald, G. W., Fisher, G. F., and Burnham, C. (1965). Diabetes, 14 473.

Malherbe, C., de Gasparo, M., Heller, F., and Hoet, J. J. (1968). 4th meeting of the European Association for the Study of Diabetes Louvain, 14 July.

Rigas, A. N., Bittles, A. H., Hadden, D. R., and Montgomery, D. A. D. (1968). British Medical fournal, 4, 25.

Roberts, H. J. (1964). Fournal of the American Geriatrics Society, 12, 423.

Siperstein, M. D., Norton, W., Unger, R. H., and Madison, L. L. (1966) Transactions of the Association of American Physicians, 79, 330.

Whichelow, M. J., Wigglesworth, A., Cox, B. D., Butterfield, W. J. H., and Abrams, M. E. (1967). Diabetes, 16, 219.

\title{
Exchangeable Potassium Study in Patients Undergoing Chronic Haemodialysis
}

\author{
Y. K. SEEDAT,* M.D., M.R.C.P., F.C.P.(S.A.)
}

British Medical fournal, 1969, 2, 344-345

Summary : Seven patients with chronic renal failure treated with haemodialysis for 4 to 24 months were found to have low exchangeable potassium levels. Before dialysis the plasma potassium was normal or somewhat raised (possibly owing to acidosis), though the exchangeable potassium was low. Acidosis was corrected during dialysis; plasma potassium levels fell, but clinical and electrocardiographic changes of hypokalaemia were absent. The level of $1 \mathrm{mEq} /$ litre in the dialysate fluid may be too low for use in prolonged haemodialysis.

\section{Introduction}

Haemodialysis is now an established procedure in the treatment of patients with chronic renal failure. The long-term effect of haemodialysis on the electrolyte changes in the patient has not been ascertained. This study was done to determine the exchangeable potassium level of patients undergoing haemodialysis for months.

\section{Material and Methods}

Seven patients undergoing chronic haemodialysis by means of a two-layered Kiil dialyser for periods ranging from 4 to 24 months were selected for this study. Exchangeable potassium levels were determined with radioactive ${ }^{42} \mathrm{~K}$ as described by Veall and Vetter (1958). Veall and Vetter stated: "The exchangeable $\mathrm{K}$ probably represents all the exchangeable potassium in normal subjects and about $90-95 \%$ in those diseased patients where equilibrium is delayed. ... Though an agreement is better if 48 hours are allowed for equilibration, this not only necessitates a fourfold increase in the tracer dose owing to the short radioactive half life, but it also makes multiple tracer studies more complicated."

With this in mind, and because of difficulties in doing a 48-hour exchangeable potassium in patients who were dialysed every second or third day, the isotope was administered orally 24 to 48 hours before dialysis, and the sample for determining specific activity was taken after a 24 -hour period for equilibra-

* University Department of Medicine, the Roypl Infirmary, Manchester 13. At present Senior Physician/S€nior Lecturer, D partment of Medicine, University of Natal, P.O. Box 39, Congella, Durban, South Africa. tion. Estimation of ${ }^{42} \mathrm{~K}$ was carried out in the saliva in patients with anuria. In patients with adequate urine output specific activity of ${ }^{42} \mathrm{~K}$ was estimated in both urine and saliva and there was a close correlation between the two results $(r=0.96$, see Table I). Plasma potassium and $\mathrm{pH}$ of the blood according to the method of Siggard Andersen et al. (1960) were done before and after dialysis. The level of potassium in the dialysate fluid was $1 \mathrm{mEq} /$ litre. The diet of the patients contained $58 \mathrm{mEq}$ of potassium per day and cation-exchange resins were not routinely used. Dialysis in Cases 1-6 were carried out three times a week and in Cases 7 and 8 twice a week. The duration of dialysis per week varied from 14 to 42 hours, and this was determined by the age and size of the patient, the need to obtain adequate control of the blood urea, plasma potassium, haemoglobin, and treatment of any complications such as peripheral neuritis.

\section{Results}

Seven of the patients who were dialysed for a period of at least four months were found to have a low exchangeable potassium level (Table I) ; the normal exchangeable potassium for males is $46 \pm 3.5 \mathrm{mEq} / \mathrm{kg}$. body weight and for females $37.5 \pm 3.2 \mathrm{mEq} / \mathrm{kg}$. body weight (de Deuxchaisnes et al., 1961). Five of the seven had an exchangeable potassium deficit of 20 to $35 \%$. The level of the exchangeable potassium was

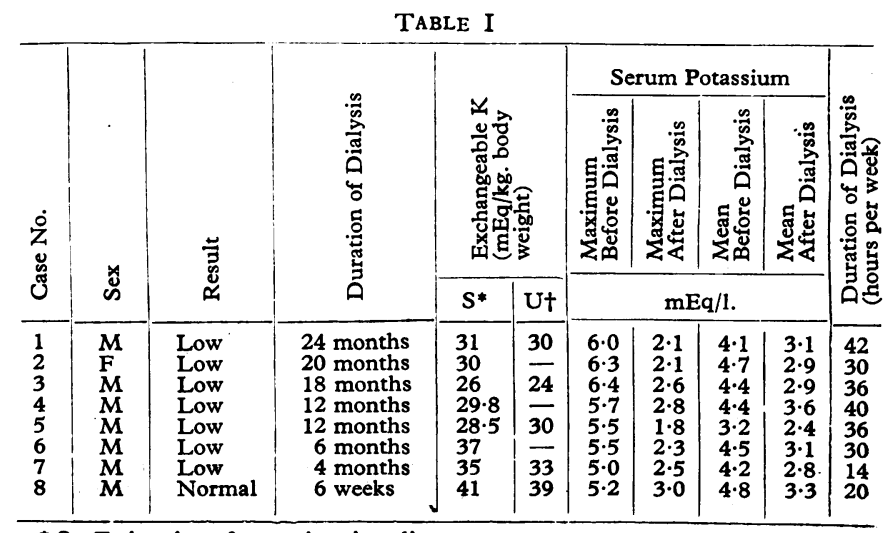
$S=$ Estimation of potassium in saliva
$+U=$ Estimation of potassium in urine. 
related to the duration of dialysis in months, and one patient (Case 8) who had dialysis for only six weeks was found to have normal exchangeable potassium. In spite of a low exchangeable potassium the predialysis potassium was normal or occasionally raised. The post-dialysis potassium was low even though clinical and electrocardiographic changes of hypokalaemia were absent. The patients were mildly acidotic before dialysis and this was corrected after dialysis (Table II). The average amount of potassium removed from the patient for a 10-hour dialysis was $150 \mathrm{mEq}$. The average faecal loss of potassium is $8 \mathrm{Eq} /$ daily (G. M. Berlyne, personal communication).

TABLE II

\begin{tabular}{c|c|c|c|c}
\hline Case No. & $\begin{array}{c}p \mathrm{H} \\
\text { Before Dialysis }\end{array}$ & $\begin{array}{c}\text { Excess Base } \\
\text { Before Dialysis } \\
\text { (mEq/1.) }\end{array}$ & $\begin{array}{c}p \mathrm{H} \\
\text { After Dialysis }\end{array}$ & $\begin{array}{c}\text { Excess Base } \\
\text { After Dialysis } \\
(\mathrm{mEq} / \mathrm{l} .)\end{array}$ \\
\hline 2 & 7.34 & -9.5 & 7.43 & -1.5 \\
3 & 7.35 & -4.5 & 7.38 & -6.0 \\
4 & 7.30 & -11.5 & 7.44 & -0.5 \\
5 & 7.41 & -3.5 & 7.44 & -2.5 \\
6 & 7.23 & -15.5 & 7.36 & -7.5 \\
7 & 7.28 & -10.2 & 7.42 & -2.5 \\
8 & 7.29 & -10.5 & 7.42 & -3.5 \\
\hline
\end{tabular}

\section{Discussion}

There are very few studies in the literature on the body potassium changes which occur after haemodialysis. Klinkmann et al. (1964) studied the influence of extracorporeal haemodialysis in six mongrel dogs after bilateral ligature of the ureters had produced a post-renal acute failure. They found that after extracorporeal haemodialysis the fall in intracellular potassium was less compared with the extracellular potassium, and they attributed this change to correction of acidosis. Klütsch (1965) studied the effect of potassium-free dialysis in 30 dogs. During potassium-free dialysis hypokalaemia with associated electrocardiographic changes was noted.

Acidosis affects the balance between intracellular and extracellular potassium directly by increasing the amount of potassium outside the cell, and a fall of $0 \cdot 1$ unit of $p \mathrm{H}$ may raise the plasma potassium level by up to $1 \mathrm{mEq} / 1$. (Douglas and Kerr, 1968). In the present study the normal to slightly raised predialysis plasma potassium in the presence of a low exchangeable potassium could be explained partially by acidosis. Isotope studies by Moore et al. (1954) indicate that high plasma potassium may exist when the total body potassium is apparently depleted.

Moderate potassium depletion up to $300 \mathrm{mEq}$ or less than $10 \%$ total body potassium produces no symptoms but more severe depletion produces dysfunction of many organs (Black, 1968). It is not known why the patients in the present study tolerated a low post-dialysis plasma potassium and potassium depletion to a remarkable extent. It is possible that associated electrolyte changes like post-dialysis alkalosis or a tolerance to chronic hypokalaemia may play a part. Elkington and Danowski (1955) stated that it is not known whether the symptoms and signs" of a low plasma potassium correlate with levels of either extracellular or cellular potassium, the ratio between the two, or the ionization of the cell potassium.

The practical significance of a low body potassium and postdialysis plasma potassium is that digitalis is relatively contraindicated in patients with cardiac failure who are undergoing haemodialysis. Potassium depletion and digitalis are additive in their effect and produce cardiac arrhythmias (Lown and Levine, 1958). An acute fall in plasma potassium after haemo- dialysis would increase the $\mathrm{K}_{\mathrm{i}}: \mathrm{K}_{\mathrm{e}}$ ratio and increase cardiac irritability. Digitalis may produce paroxysmal auricular tachycardia in the presence of a low body potassium even though the plasma potassium is normal (Oram et al., 1960). A low body potassium leads to impairment of carbohydrate tolerance (Conn, 1965) and it is possible that impairment of carbohydrate metabolism will develop in patients undergoing chronic haemodialysis who develop potassium depletion. As previously stated (Seedat, 1968) correction of any potassium deficiency is mandatory in these patients, especially if large amounts of glucose are used in the dialysate fluid. This work shows that plasma potassium can be controlled by thrice-weekly dialysis against a low potassium bath water without the use of cation-exchange resins as advocated by Papadimitriou et al. (1968) provided the dietary potassium intake is less than $70 \mathrm{mEq}$ daily. It confirms the statements of Berlyne (1968) and Bone and Davison (1968) that it is unnecessary to use cation-exchange resins in adequately dialysed patients.

It is possible that a potassium level of $1 \mathrm{mEq} /$ litre in the dialysate fluid (de Wardener, 1968) to lessen the risk of fatal hyperkalaemia between dialysis may be too low and that further work is necessary to determine the ideal level in patients undergoing haemodialysis for a prolonged period. However, it must be emphasized that a normal serum potassium level has been achieved at the expense of producing potassium depletion and there is no guarantee that equally adequate dialysis against a higher potassium bath water would prevent hyperkalaemia if cation-exchange resins were omitted.

I am indebted to Professor D. A. K. Black for his helpful criticisms in the preparation of this paper, to Dr. G. M. Berlyne for his interest and encouragement, and to the nurses of the haemodialysis unit for their loyalty and help in the study.

This project was done while on study leave from the University of Natal.

\section{REFERENCES}

Andersen, O. S., Engel, K., Jørgenson, J., and Astrup, P. (1960). Scandinavian fournal of Clinical and Laboratory Investigations, 12, 172.

Berlyne, G. M. (1968). Lancet, 2, 1190.

Black, D. A. K. (1968). Essentials of Fluid Balance, p. 86. Oxford, Blackwell.

Bone, M., and Davidson, A. M. (1968). Lancet, 2, 1137.

Conn, J. W. (1965). New England Fournal of Medicine, 273, 1135.

de Deuxchaisnes, C. N., Collet, R. A., Busset, R., and Mach, R. S. (1961). Lancet, 1, 681.

de Wardener, H. E. (1968). In Fourth Symposium on Advanced Medicine, edited by O. M. Wrong, p. 134. London, Pitman Medical.

Douglas, A. P., and Kerr, D. N. S. (1968). A Short Textbook of Kidney Disease, p. 88. London, Pitman Medical.

Elkington, J. R., and Danowski, T. S. (1955). The Body Fluids : Basic Physiology and Practical Therapeutics, p. 184. Baltimore, Williams \& Wilkins.

Klinkmann, H., Holtz, M., and Schwarz, F. (1964). Deutsches Archiv für klinische Medizin, 209, 676.

Klütsch, K. (1965). Archiv. für Kreislaufforschung, 47, 246.

Lown, B., and Levine, H. D. (1958). Atrial Arrhythmias, Digitalis, and Potassium. New York, Landsberger.

Moore, F. D., Edelman, I. S., Olney, J. M., James, A. H., Brooks, L., and Wilson, G. M. (1954). Metabolism, 3, 334.

Oram, S., Resnekov, L., and Davies, P. (1960). British Medical fournal, 2, 1402 .

Papadimitriou, M., Gingell, J. C., and Chisholm, G. D. (1968). Lancet, 2, 948 .

Seedat, Y. K. (1968). Lancet, 2, 1166

Veall, N., and Vetter, H. (1958), Radioisotope Techniques in Clinical Research and Diagnosis, p. 202. London, Butterworths. 